\title{
INVENTARISASI JENIS GULMA DI AREAL PERTANAMAN CENGKEH (Syzygium aromaticum L.) DI NEGERI ALLANG KECAMATAN LEIHITU BARAT KABUPATEN MALUKU TENGAH
}

\author{
Inventory of Weed Spices in Plantation of Clove (Syzygium aromaticum L.) in \\ Allang Village Central Mollucas District
}

\author{
Vilma L Tanasale, Dessy A. Marasabessy, Nureny Goo \\ Jurusan Budidaya Pertanian, Universitas Pattimura \\ JI Ir M Putuhena, Kampus Poka, Ambon 97233 \\ *Korespondensi penulis, Email: vilmalaurientanasale@gmail.com
}

Diterima: Oktober 2020

Disetujui terbit: Desember 2020

\begin{abstract}
Clove (Syzygium aromaticum L.) is a spice cultivated in Mollucas. Recently the population of clove plant is decreasing due to weeds that impended the growth of clove. The identification of weeds is the first step in controlling weeds. However, until recently there has been no research on the influence of inventaritation of weed spices in important as the base of an accurate weed control. This research on weed inventaritation clove planting area is important as the base of an accurate is based on Sum Dominance Ratio (SDR), at the clove plant areal in Allang Vilagge, Village Central Mollucas District. This research using weed survey method type quadrat method with sample plot size $1 \times 1 \mathrm{~m}$. The result showed that there were 23 species of weed, with details of 18 broad-leaf weed, 4 grasses, and 1 cyperaceae in the clove areal planting in Allang village

Keywords: clove, dominant weeds, weed inventaritation, weed vegetation analysis
\end{abstract}

\begin{abstract}
ABSTRAK
Cengkih (Syzygium aromaticum. L) merupakan salah satu tanaman rempah yang dibudidayakan di Maluku. Walaupun tanaman cengkih produktif namun telah terjadi penurunan produksi secara terus menerus, karena adanya kehadiran gulma. Pengenalan jenis-jenis gulma dominan merupakan langkah awal dalam menentukan keberhasilan pengendalian gulma. Data inventarisasi jenis gulma sangat penting dalam menghitung nilai SDR pada areal pertanaman cengkih di Negeri Allang, Kabupaten Maluku Tengah. Penelitian ini menggunakan metode kuadrat dengan petak sampel ukuran $1 \times 1 \mathrm{~m}$. Hasil penelitian menunjukkan adanya 23 jenis gulma, antara lain 8 jenis gulma daun lebar, 4 gula rerumputan dan 1 gulma tekian pada areal pertanaman cengkih di Negeri Allang.

Kata kunci: analisis vegetasi, cengkih, gulma dominan, inventarisasi gulma
\end{abstract}

\section{PENDAHULUAN}

Maluku merupakan salah satu provinsi penghasil rempah-rempah seperti pala dan cengkeh (Palijama, 2012). Salah satu Negeri di Maluku Tengah yang membudidayakan cengkih dalam jumlah yang banyak adalah Negeri Allang. Negeri Allang merupakan negeri yang berpotensial bagi pertanaman cengkih di Maluku Tengah. Tanaman cengkih ini dapat dibudidayakan pada dataran tinggi maupun dataran rendah, namun lebih produktif pada dataran rendah. 
Walaupun tanaman cengkih produktif namun telah terjadi penurunan produksi secara terus menerus. Berdasarkan data BBP2TP (2012), cengkih di Maluku Tengah mengalami penurunan. Penurunan produksi cengkih secara drastis dari tahun ke tahun di Negeri Allang disebabkan oleh adanya kehadiran gulma. Kehadiran gulma secara langsung dan tidak langsung mengganggu pertumbuhan tanaman cengkih.

Gulma merupakan salah satu organisme pengganggu tanaman yang menghambat pertumbuhan dan produktivitas tanaman. Kerugian yang diakibatkan oleh gulma dibagi menjadi dua kategori yaitu secara langsung dan secara tidak langsung (Moenandir, 1985). Menurut Moenandir, gulma dikatakan jahat karena dapat memberikan pengaruh negatif terhadap pertumbuhan tanaman budidaya disekitarnya.

Kehadiran gulma jika dibiarkan secara terus menerus tanpa dikendalikan akan merugikan tanaman cengkih dan berpengaruh pada produksi cengkih karena gulma akan menjadi inang hama dan penyakit. Selain itu, gulma juga menyebabkan persaingan pada fase pertumbuhan tanaman cengkih dalam memperebutkan hara, air, cahaya, ruang tumbuh akan digunakan secara bersamaan sehingga unsur-unsur penunjang pertumbuhan tidak akan tersedia bagi tanaman cengkih (Najiyati dan Danarti, 2003).

Menurut Riry (2008), gulma menyaingi tanaman dalam pengambilan unsur hara, air, ruang, $\mathrm{CO}_{2}$ dan cahaya. Gulma juga mempunyai tiga peranan penting yaitu sebagai alelospoli, alelopati, dan alelomediasi. Gulma sebagai alelospoli karena bersifat monopoli atas air, unsur hara, $\mathrm{CO}_{2}, \mathrm{O}_{2}$, dan sinar matahari. Secara umum persaingan antara tanaman dan gulma dapat mengakibatkan pertumbuhan tanaman budidaya menjadi tertekan, menghambat kelancaran aktifitas pertanian, estetika lingkungan menjadi tidak nyaman serta meningkatkan biaya pemeliharaan (Tanasale, 2010).

Untuk mengatasi masalah kehadiran gulma pada areal pertanaman cengkih di Negeri Allang maka perlu adanya upaya pengendalian gulma dengan cara mengenal jenis-jenis gulma penyusun vegetasi diareal pertanaman cengkih.

Pengenalan jenis-jenis gulma dominan merupakan langkah awal yang menentukan keberhasilan pengendalian gulma (Tanasale, 2012). Maka dari itu perlu adanya penelitian 
tentang inventarisasi jenis gulma di areal pertanaman cengkeh (Syzygium aromaticum. L) di Negeri Allang, Kecamatan Leihitu Barat, Kabupaten Maluku Tengah.

Penelitian ini bertujuan untuk menginventarisir jenis-jenis gulma dominan di areal pertanaman cengkeh di Negeri Allang, Kecamatan Leihitu Barat, Kabupaten Maluku Tengah.

\section{METODE PENELITIAN}

\section{Lokasi dan Waktu Penelitian}

Penelitian ini dilaksanakan di Negeri Allang, Kecamatan Leihitu Barat, Maluku Tengah. Pelaksanaan penelitian ini berlangsung di lapangan pada bulan Mei hingga Juni 2019.

\section{Alat dan Bahan, Metode, dan Teknik Pengumpulan Data}

Alat yang digunakan dalam penelitian ini adalah kamera, soil tester, termometer, frame ukuran $1 \times 1$ $\mathrm{m}$, cutter, oven, dan alat tulis. Bahan yang digunakan dalam penelitian ini adalah jenis gulma pada areal pertanaman cengkih, label, kantung platik, amplop, dan tabel pengamatan.

Metode yang digunakan dalam penelitian ini adalah Metode Kuadrat dengan menggunakan petak sampel ukuran 1x1 m. Pengambilan sampel dilakukan di bawah tajuk tanaman cengkeh pada areal pertanaman cengkeh di Negeri Allang. Pengambilan sampel tanaman sebanyak 6 sampel dan diulang sebanyak 3 kali pada setiap sampel tanaman sehingga diperoleh 18 petak sampel pengamatan. Delapan belas petak sampel pengamatan ini diambil pada pohon cengkih pada umur tanaman 40-45 tahun dengan tinggi tanaman kurang lebih 14-16 m. Gulma yang terdapat dalam petak sampel dicabut dari permukaan tanah, kemudian dimasukkan kedala kantong plastik, setelah itu diidentifikasi jenisnya. Gulma yang telah diidentifikasi dimasukan ke dalam amplop yang telah diberi label sesuai dengan petak sampel pengamatan, untuk dioven dan dilakukan pengukuran berat kering konstan.

Data yang diperlukan dalam penelitian ini terdiri atas data primer dan data sekunder. Data primer diperoleh dari pencatatan angka dari pengamatan jumlah kehadiran individu tiap jenis gulma dan biomassa (berat kering) setiap petak sampel. Sedangkan data sekunder berupa data umum wilayah (keadaan umum lokasi) dan data iklim (curah hujan) untuk 5 tahun terakhir, sebagai bahan pembanding, berupa parameter di ukur langsung di lapangan seperti $\mathrm{pH}$ 
tanah, kelembaban tanah, dan suhu yang diukur pada ketinggian $100 \mathrm{~m}$.

\section{Teknik Analisis Data}

Data yang terkumpul kemudian dianalisis secara deskripsi kuantitatif. Penghitungan kerapatan dan frekuensi serta dominasi gulma, digunakan rumus menurut (Tjitrosoedirdjo et al. 1984) sebagai berikut:

$$
\begin{aligned}
& K R=\frac{\text { kerapatan mutlak spesies tertentu }}{\text { jumlah kerapatan mutlak semua jenis }} \\
& F R=\frac{\text { frekuensi mutlak satu spesies }}{\text { frekuensi semua jenis }} \times 100 \% \\
& B R=\frac{\text { biomassa mutlak spesies tertentu }}{\text { jumlah biomassa mutlak semua jenis }} \\
& \times 100 \%
\end{aligned}
$$

Sum Domination Ratio $(S D R)=\frac{K R+F R+B R}{3}$

Keterangan: Kerapatan Mutlak (KM), Kerapatan Relatif (KR), Frekuensi Mutlak (FM), Frekuensi Relatif (FR), Biomassa Mutlak (BM), Biomassa Relatif (BR).

\section{HASIL DAN PEMBAHASAN}

\section{Keadaan Umum Lokasi Negeri Allang}

Negeri Allang terletak di Kecamatan Leihitu Barat, Kabupaten Maluku Tengah dengan luas $20,42 \mathrm{~km}^{2}$ atau $24,17 \%$ dari luas keseluruhan kecamatan Leihitu Barat. Luas areal yang digunakan untuk perkebunan yaitu 200 ha, di mana 50,5 ha digunakan sebagai areal pertanaman cengkeh yang dengan jumlah petani 854/KK. Negeri Allang memiliki topografi wilayah yang terdiri dari daratan dan bukit dengan ketinggian 0 - 535 m dari permukaan laut. Lokasi penelitian berada pada ketinggian 120 mdpl.

\section{Iklim Daerah Penelitian}

Penilaian keadaan curah hujan dari hari hujan di daerah penelitian didasarkan atas data hujan dan hari hujan yang diperoleh dari stasiun meteorologi selama periode pencatatan 6 tahun terakhir. Total ratarata curah hujan di daerah penelitian sebesar 4,066 mm, di mana bulanbulan basah terjadi pada bulan Mei dan September dengan kisaran ratarata curah hujan sebesar $697 \mathrm{~mm}$ dan $253 \mathrm{~mm}$, dengan curah hujan tertinggi terjadi pada bulan Juli. Bulan lembab terjadi antara bulan Januari-April, Juli, Agustus, September dan Desember dengan kisaran rata-rata curah hujan bulanan sebesar $187 \mathrm{~m}$. Sedangkan bulan kering terjadi pada bulan Oktober dan November dengan curah hujan sebesar $100 \mathrm{~m}$. 
INVENTARISASI JENIS GULMA DI AREAL PERTANAMAN CENGKEH

(Syzygium aromaticum L.) DI NEGERI ALLANG KECAMATAN LEIHITU BARAT

KABUPATEN MALUKU TENGAH. Yana Vilma L Tanasale, Nurenny Goo, Riry

\section{Komposisi dan Struktur Vegetasi Gulma}

Dari hasil pengamatan gulma di Negeri Allang menunjukan bahwa di areal pertanaman cengkeh terdapat 23 jenis gulma dari 18 jenis famili gulma daun lebar, 4 jenis famili gulma rerumputan, dan 1 jenis famili gulma tekian. Tabel 1 menjelaskan Nilai SDR Tanaman Cengkeh Tanaman Menghasilkan di Daerah Penelitian.

Tabel 1 Nilai SDR tanaman cengkeh tanaman menghasilkan di daerah penelitian

\begin{tabular}{|c|c|c|c|}
\hline \multirow{2}{*}{\multicolumn{4}{|c|}{$\begin{array}{l}\text { No Jenis gulma } \\
\text { Gulma daun lebar }\end{array}$}} \\
\hline & & & \\
\hline \multicolumn{4}{|c|}{ Broad leaf } \\
\hline \multicolumn{4}{|c|}{ Convolvulaceae } \\
\hline 1 & $\begin{array}{l}\text { Ipomoea purourea } \\
\text { Mackinlayaceae }\end{array}$ & Semusim & 1,68 \\
\hline 2 & $\begin{array}{l}\text { Centella asiatica } \\
\text { Onagraceae }\end{array}$ & Tahunan & 1,85 \\
\hline 3 & Epilobium hirsutum & Tahunan & 0,70 \\
\hline 4 & $\begin{array}{l}\text { Circaea lutetiana. } L \\
\text { Araceae }\end{array}$ & Tahunan & 0,72 \\
\hline 5 & Epipremnum aureum & Tahunan & 2,68 \\
\hline 6 & Anthurium warocqueanum & Tahunan & 0,68 \\
\hline 7 & Caladium bicolor & Tahunan & 0,68 \\
\hline 8 & Caladium white chistmas & Tahunan & 1,19 \\
\hline 9 & $\begin{array}{l}\text { Dieffenbachia seguine } \\
\text { Lygodiaceae }\end{array}$ & Tahunan & 1,05 \\
\hline 10 & $\begin{array}{l}\text { Lygodium circinnatum } \\
\text { Verbenaceae }\end{array}$ & Tahunan & 2,30 \\
\hline 11 & $\begin{array}{l}\text { Stachytarpheta jamaincensis } \\
\text { Balsamina }\end{array}$ & Semusim & 3,38 \\
\hline 12 & $\begin{array}{l}\text { Impatiens balsamina.L } \\
\text { Malvaceae }\end{array}$ & Tahunan & 3,33 \\
\hline 13 & $\begin{array}{l}\text { Urena Lobata } \\
\text { Lauraceae }\end{array}$ & Tahunan & 2,09 \\
\hline 14 & $\begin{array}{l}\text { Ocotea cinerea } \\
\text { Lomariopsidaceae }\end{array}$ & Tahunan & 1,60 \\
\hline 15 & Nephrolepis bisserrata & Tahunan & 5,23 \\
\hline 16 & $\begin{array}{l}\text { Neprholepis exaltata } \\
\text { Piperaceae }\end{array}$ & Semusim & 5,02 \\
\hline 17 & $\begin{array}{l}\text { Piper betle } \\
\text { Melastomataceae }\end{array}$ & Tahunan & 1,77 \\
\hline 18 & Clidemia hirta & Tahunan & 7,29 \\
\hline \multicolumn{4}{|c|}{$\begin{array}{l}\text { Gulma Rerumputan } \\
\text { Poaceae }\end{array}$} \\
\hline 19 & Digitaria setigera & Semusim & 32,38 \\
\hline 20 & Imperata cylinrica & Tahunan & 9,22 \\
\hline 21 & Paspalum conjungatum & Tahunan & 4,50 \\
\hline 22 & Eleusine indica & Tahunan & 6,10 \\
\hline \multicolumn{4}{|c|}{$\begin{array}{l}\text { Gulma Tekian } \\
\text { Cyperaceae }\end{array}$} \\
\hline 23 & Ciperus rotundus & Tahunan & 2,04 \\
\hline & & Total & 100 \\
\hline
\end{tabular}


Berdasarkan Nilai SDR-nya gulma yang dominan pada areal pertanaman cengkeh adalah jenis gulma Digitaria setigera (32,38 persen) dari suku poaceae. Tumbuhan ini dinyatakan sebagai gulma dominan. Urutan keduanya yaitu gulma Imperata cylindrica dengan nilai SDR 9,22 persen dari suku poaceae. Urutan ketiga adalah gulma Clidemia hirta dengan nilai SDR 7,29 dan jenis gulma ini termasuk gulma berdaun lebar.

Urutan keempat jenis gulma Eleusine indica dengan nilai SDR 6,10. Gulma ini termasuk suku poaceae. Urutan kelima jenis gulma Nephrolepis bisserrata dengan nilai SDR 5,23 dari suku. Hasil pengukuran $\mathrm{pH}$ tanah pada areal pertanaman cengkih adalah $\mathrm{pH}$ tanah masam 5,12. Hasil pengukuran kelembaban tanah menunjukkan pada areal pertanaman cengkih sebesar 45,55. Hasil pengukuran suhu udara pada areal pertanaman cengkih pada siang hari $26,55^{\circ} \mathrm{C}$.

Gulma Digitaria setigera dengan nilai $\operatorname{SDR}(32,38$ persen) termasuk, famili Poaceae. Berdasarkan siklus hidupnya gulma ini merupakan gulma semusim, akan tetapi tingkat penyebarannya juga cukup tinggi karena gulma ini mampu menyebar pada areal pertanaman cengkih. Tingkat penyebaran biji gulma yang tinggi ini dipengaruhi oleh angin, manusia, dan hewan.

Gulma ini mampu tumbuh pada semua ketinggian tempat tetapi dominan pada ketinggian $100 \mathrm{mdpl}$ karena gulma ini dapat beradaptasi pada daerah dengan suhu udara tinggi, kelembaban tanah rendah, $\mathrm{pH}$ tanah asam. Selain itu, juga intensitas cahaya yang tinggi pada ketinggian 100 mdpl yang menyebabkan suhu udara tinggi, kelembaban tanah rendah memungkinkan gulma rerumputan Digitaria setigera lebih banyak ditemukan pada ketinggian 100 mdpl. Hal ini mengindikasikan bahwa gulma ini lebih banyak menyukai tempat yang terbuka dari pada tempat yang ternaungi.

Gulma Imperata cylindrica dengan nilai SDR $(9,22 \%)$ merupakan gulma tahunan yang dapat berkembang biak dengan cepat. Benih-benihnya yang ringan mudah diterbangkan angin sehingga mudah jatuh dan tumbuh pada areal pertanaman cengkih. Selain itu, kemampuan bertumbuh dan berkembang biak melalui bagian vegetatif akar rimpang memungkinkan gulma ini dapat tumbuh dengan cepat.

Selain itu gulma Imperata cylindrica memiliki zat beracun yang bernama alelopatti yang dapat 
INVENTARISASI JENIS GULMA DI AREAL PERTANAMAN CENGKEH

digunakan untuk menghambat pertumbuhan gulma lainnya maupun menghambat pertumbuhan tanaman cengkih pada fase tanaman belum menghasilkan.

\section{Gulma Imperata cylindrica} memiliki kemampuan adaptasi yang tinggi pada berbagai jenis tanah dan pada daerah dengan intensitas cahaya rendah sampai tinggi. Dengan kemampuan tumbuh yang cukup tinggi dan daya penyebaran yang cepat maka gulma ini dapat tumbuh dan menyebar diareal pertanaman cengkih.

Gulma Clidemia hirta dengan nilai SDR $(7,29 \%)$ merupakan gulma perdu tahunan, gulma yang tangguh dengan perakarannya yang kuat dan batangnya yang keras. Tumbuhan ini sering dijumpai di tepi hutan, semak belukar, di tepi jurang, daerah terbuka dan terganggu seperti pinggiran jalan, padang rumput dan perkebunan. Penyebaran gulma Clidemia hirta oleh burung atau melekat pada bulu binatang selain itu manusia juga penyebab penyebaran gulma ini, memiliki bunga mejemuk, berbulu, ujung meruncing, jumlah bunga 6-20. Gulma ini mampu beradaptasi pada kondisi daerah dengan kelembaban yang rendah sampai tinggi, dan sarana tumbuh mendukung seperti $\mathrm{pH}$ tanah yang asam suhu udara $26,55{ }^{\circ} \mathrm{C}$ sangat mendukung perbanyakan gulma ini.

Biji gulma ini sangat kecil dan halus sehingga mudah diterbangkan angin, mudah melekat pada binatang dan manusia sehingga tinggi tingkat penyebaranya, selain itu juga gulma ini mampu berkembang dengan organ vegetatifnya. Selain itu juga gulma ini merupakan gulma tahunan sehingga dapat berkembang biak baik secara vegetatif dan generatif. Alat perkembangbiakan inilah yang mampu meningkatkan perkembangbiakan dan penyebarannya. Utomo (2012) menyatakan bahwa gulma ini tumbuh pada tanah yang lembab atau agak kering, lokasi terbuka atau ternaungi.

Hal ini mengindikasikan bahwa gulma Clidemia hirta mampu tumbuh dan menyebar pada kondisi ternaungi pada tingkat kelembaban tanah yang tinggi maupun kondisi terbuka dengan tingkat kelembaban rendah.

Berdasarkan nilai SDR gulma Eleusina indica $(6,10 \%)$ merupakan gulma semusim. Memiliki sistem perakaran yang dangkal namun cukup lebat dan sangat kuat menjangkar pada tanah sehingga memiliki kemampuan untuk menyerap unsur hara lebih cepat dan memiliki daya saing yang tinggi. 
Perkembangbiakannya terutama melalui biji, biji yang dimiliki dalam jumlah yang banyak, berukuran kecil dan ringan sehingga mudah menyebar terbawa angin maupun alat pertanian (Nasution, 1983).

Eleusina indica dapat berbunga sepanjang tahun dan setiap individunya mampu menghasilkan biji 140.000 biji setiap musimnya sehingga cepat dalam penyebarannya (Lee dan Ngim, 2000). Kemampuan menghasilkan biji dalam jumlah yang banyak ini memungkinkan gulma ini mudah menyebar karena mudah diterbangkan angin di areal pertanaman cengkih sehingga gulma ini memiliki kemampuan memperbanyak diri dengan cepatnya.

Hal ini yang menyebabkan gulma Eleusina indica dominan kekempat pada areal pertanaman cengkih. Bentuk tajuk dari tanaman cengkeh memungkinkan sinar matahari dapat memancarkan cahayanya sampai ke permukaan tanah menyebabkan gulma jenis rerumputan lebih mudah untuk tumbuh dan berkembang, karena jenis gulma rerumputan lebih membutuhkan penyinaran yang lebih dari pada jenis gulma daun lebar.

Gulma Neprolepis bisserata berkembang biak dengan spora yang terletak di pinggiran daun. Gulma ini, dapat dijumpai pada areal pertanaman cengkeh dengan nilai SDR $(5,23 \%)$ Hal ini mengindikasikan bahwa gulma ini lebih banyak menyukai tempat yang terbuka dari pada tempat yang ternaungi.

Suhu udara, kelembaban tanah, dan $\mathrm{pH}$ tanah yang sesuai dengan syarat tumbuh gulma ini memungkinkan gulma ini bertumbuh dengan cepat di areal pertanaman cengkih. Selain itu juga berdasarkan daur hidupnya gulma Neprolepis bisserata merupakan gulma tahunan yang mampu berkembang biak secara vegetatif dan generatif sehingga memiliki daya kompetisi tinggi.

Gulma ini berkembang biak dengan spora dan rumpun memungkinkan gulma ini untuk berkembang biak dengan cepat, sehingga mampu menempati habitat yang luas dari tempat yang lembab sampai lokasi terbuka, diberbagai tempat di pegunungan dan di gurun yang kering, sungai atau di lapangan terbuka (Tanasale, 2010).

Suhu yang tinggi, kelembaban tanah yang rendah dengan $\mathrm{pH}$ tanah asam juga dapat mempercepat pertumbuhan dan perkembanganya. Hal ini yang menyebabkan gulma ini dapat berkembangbiak dengan cepat 
dan mampu beradaptasi pada areal pertanaman. Kemampuan menyebar yang tinggi pada gulma ini memungkinkan gulma ini mampu tumbuh dan berkembang pada setiap ketinggian tempat.

Berdasarkan jumlah jenis gulma, komunitas gulma berdaun lebar memiliki komunitas gulma yang lebih banyak dari pada jenis gulma rerumputan dan tekian pada areal pertanaman cengkih ini. Gulma daun lebar memiliki kemampuan menyerap unsur hara dan air lebih banyak dari gulma lainnya, dengan demikian gulma ini memiliki daya kompetisi yang tinggi dengan gulma lain sehingga gulma ini mampu tumbuh dan berkembang serta mendominasi areal ini.

Areal pertanaman cengkeh terletak pada ketinggian $120 \mathrm{mdpl}$ sehingga gulma berdaun lebar memiliki kemampuan untuk menyesuaikan diri lebih cepat dengan lingkungan tumbuhnya. Jika ketinggian tempat bertambah maka suhu akan menurun dan kelembaban tanah tinggi sehingga gulma daun lebar mampu beradaptasi dengan cepat. Selain itu gulma daun lebar juga memiliki kemampuan beradaptasi pada $\mathrm{pH}$ tanah masam. Derajat keasaman tanah pada ketinggian areal pertanaman cengkeh di Negeri Allang termasuk $\mathrm{pH}$ tanah masam, sehingga gulma daun lebar memiliki kemampuan beradaptasi yang tinggi di Negeri Allang.

\begin{tabular}{|c|c|}
\hline Negeri & Allang \\
\hline berketinggian & tempat 120 \\
\hline
\end{tabular}
menyebabkan air tanah mengalir dalam suatu garis aliran dari tanah mengalir dalam suatu garis aliran dari tempat yang tinggi ke tempat yang rendah atau dari lereng bagian atas ke lereng bagian bawah mengikuti bentuk kesetimbangan. Kemiringan lereng terjadi akibat perubahan permukaan bumi di berbagai tempat yang disebabkan oleh daya-daya eksogen dan gaya-gaya endogen yang terjadi sehingga mengakibatkan perbedaan letak ketinggian titik-titik diatas permukaan bumi. Kemiringan lereng mempengaruhi erosi melalui runoff. Makin curam lereng makin besar laju dan jumlah aliran permukaan dan semakin besar erosi yang terjadi. Selain itu partikel tanah yang terpercik akibat tumbukan butir hujan makin banyak (Arsyad, 2000). Akibat runoff ini maka basa-basa akan ikut terlarut sehingga mengakibatkan $\mathrm{pH}$ tanah pun akan menjadi masam.

Kondisi $\mathrm{pH}$ tanah yang masam dengan kelembaban tanah yang tinggi 
menyebabkan lebih banyak spesies gulma golongan daun lebar, dari pada gulma rerumputan dan tekian, karena gulma golongan daun lebar lebih banyak menggunakan air sehingga pertumbuhannya lebih cepat. Semakin tinggi ketinggian tempat kelembaban tanah semakin rendah sehingga spesies gulma daun lebar lebih mampu bertahan hidup dari pada gulma rerumputan, mengakibatkan jenis gulma daun lebar (18 jenis) lebih banyak dari pada jenis gulma rerumputan (4 jenis).

Keragaman dan perbedaan jenis gulma pada areal pertanaman cengkih pada setiap ketinggian tempat sangat dipengaruhi oleh faktor lingkungan antara lain ketinggian tempat, suhu udara, kelembaban tanah, $\mathrm{pH}$ tanah, cara perbanyakan dan penyebaran gulma. Faktor-faktor inilah yang mendukung kehadiran suatu jenis gulma pada suatu tempat.

Keberhasilan dari pengendalian gulma harus didasarkan pada pengetahuan yang cukup tentang sifat biologi gulma. Berdasarkan hasil nilai SDR gulma rerumputan memiliki nilai SDR tertinggi dari pada gulma daun lebar dan tekian akan tetapi karena jumlah jenis gulma daun lebar mendominasi areal pertanaman cengkih, maka disarankan cara pengendalian gulma yang tepat yaitu dengan cara pengendalian mekanik dengan cara pembabatan secara periodik selang 2-3 minggu dan secara kimiawi dengan herbisida sistemik untuk mematikan gulma rerumputan dan daun lebar misalnya glifosat.

\section{SIMPULAN DAN SARAN}

\section{Simpulan}

Keberhasilan usaha ternak sapi potong ditentukan oleh salah satu faktor terbesar, yaitu pakan. Rendahnya pemanfaatan limbah pertanian khususnya kulit singkong untuk pakan alternatif ternak menjadi faktor penting untuk penerapan inovasi. Salah satu inovasi yang digunakan yaitu fermentasi.

Berdasarkan

penelitian dilapangan mengenai pemanfaatan fermentasi kulit singkong untuk pakan alternatif sapi potong, menunjukkan adanya dampak yang bagus terhadap pertambahan bobot badan sapi potong dengan rata-rata 795 gram/ekor/hari. Inovasi tersebut bisa menjadi contoh keberhasilan dalam pemanfaatan inovasi yang cukup mudah dikalangan petani ternak.

\section{Saran}

$\begin{array}{clr}\text { Untuk } & \text { meningkatkan sektor } \\ \text { pertanian } & \text { khususnya } & \text { bidang }\end{array}$


peternakan, diperlukan sumberdaya alam dan sumberdaya manusia yang baik dan berkualitas. Dukungan tersebut tidak terlepas dari peran pemerintah, serta penyuluh pertanian yang berfungsi sebagai pembawa informasi untuk disampaikan kepada petani ternak.

\section{DAFTAR PUSTAKA}

Arsyad S. 2000. Konservasi Tanah dan Air. Institut Pertanian Bogor Press. Bogor.

BB2PTP Ambon. 2012.

Perkembangan Serangan OPT

Penting Tanaman Perkebunan

Triwulan IV Ambon.

Lee LJ, Ngim J. 2000. Control of Asystasia intrusa (BI) In Pineapple with Emphasis on New Techniques. Papper presented at the Seminar and Discussion on the Weed Asystasia, West Johore Agric. Dev. Project, Pontian, 16pp.

Moenandir, J. 1985. Pengantar IImu Gulma dan Pengendalian Gulma. IImu Gulma I. Rajawali Press : Jakarta

Najiyati S, Danarti. 2003. Budidaya dan Penanganan Pascapanen Cengkeh. Edisi Revisi. Penebar Swadaya : Jakarta
Nasution, A. 1983. Aplikasi Beberapa Dosis Herbisida Glifosat dan Parquat pada Sistem Tanpa Olah Tanah (TOT) serta Pengaruhnya terhadap Sifat Kimia Tanah, Karakteristik Gulma dan Hasil kedelai. Jurnal Agrista. 16(3) : 135-145

Palijama W, Riry J, Watimena A. Komunitas Gulma Pada Pertanaman Pala (Myristica fragrans $\mathrm{H}$ ) belum Menghasilkan dan Menghasilkan di Desa Hutumuri Kota Ambon. Ambon : Jurnal IImu Budidaya Tanaman . Vol. 1 No . 2 : 134 - 142

Riry, J. 2008. Mengenal gulma dan Pengelolaannya di Indonesia. Bogor : CVD'sainku Advertising. Sastroutomo SS. 1990. Ekilogi Gulma. Jakarta : Gramedia Pustaka Utama.

Tanasale V. 2010. Komunitas Gulma Pada Pertanaman Gandaria Belum Menghasilkan dan Menghasilkan Pada ketinggian Tempat Yang Berbeda. (Tesis ) UGM. Yogyakarta.

Tjitrosoedirdjo S, Utomo $\mathrm{IH}$, Wiroatmodjo J. 1984. Penggelolaan Gulma di perkebunan. PT Gramedia: Jakarta. 